\title{
Hemigrammus ataktos: a new species from the rio Tocantins basin, central Brazil (Characiformes: Characidae)
}

\author{
Manoela M. F. Marinhoํㅜ Fernando C. P. Dagosta ${ }^{1}$ and José L. O. Birindelli²
}

A new species of Hemigrammus is described from the middle rio Tocantins basin, central Brazil. The new species can be distinguished from all congeners by having a black midlateral stripe on the body extending from the posterior margin of the eye to the median caudal-fin rays. Mature males possess dorsal-, pelvic-, and anal-fin rays elongate, features that also help to recognize the new species. Although the new species is described in Hemigrammus, some specimens present a complete series of pored scales in the lateral line. A discussion about the generic allocation of the new species is presented.

Uma espécie nova de Hemigrammus é descrita da bacia do médio rio Tocantins, Brasil central. A espécie nova distingue-se de seus congêneres por apresentar uma faixa mediana negra na lateral do corpo desde a margem posterior do olho até os raios medianos da nadadeira caudal. Machos maduros apresentam os raios das nadadeiras dorsal, pélvica e anal alongados, características que também auxiliam o reconhecimento da espécie. Apesar da espécie nova ser descrita em Hemigrammus, alguns exemplares possuem série completa de escamas perfuradas na linha lateral. Uma discussão sobre o posicionamento genérico da espécie nova é apresentada.

Key words: Lateral line, Neotropical fish, Systematics, Taxonomy, Tetras.

\section{Introduction}

The Characiformes is one of the largest orders of fishes with approximately 2000 valid species exclusively distributed in Africa, South of North America, Central, and South America (Eschmeyer, 2013). The Characidae itself encompasses slightly more than half of the number of species in the order, and includes mostly small-sized species generally referred to as "tetras", many of which just recently described (e.g., Ingenito et al., 2013; Mattox et al., 2013) or still waiting to be discovered.

During a recent expedition to upper and middle portions of the rio Tocantins, a new species of Hemigrammus Gill, 1858 was discovered. The examination of representatives of Characidae deposited in collections (CAS, MZUSP, and ZUEC) evidenced that this species had been previously collected several times but remained unknown for nearly ninety years. The new species is similar in coloration to a group of species of Hyphessobrycon Durbin, 1908 referred by Géry (1977) as the Hyphessobrycon heterorhabdus group, characterized by having a dark straight and relatively narrow midlateral stripe on the body, from the opercle to the caudal peduncle. However, the new species possesses small scales largely covering the caudal-fin lobes, which are absent in all species of Hyphessobrycon. The presence of scales covering the caudal-fin lobes, however, is one of the features that traditionally define the genera Hemigrammus and Moenkhausia Eigenmann, 1903 (e.g., Eigenmann, 1917; Géry, 1977). Furthermore, the new species presents variable lateral-line perforation, an unusual or poorly documented condition among the species of Characidae.

Based on its unique combination of morphological features, the new species is herein formally described and diagnosed from all other species of the family. Its generic assignment is discussed according to the current knowledge of species of the Characidae.

\footnotetext{
${ }^{1}$ Museu de Zoologia da Universidade de São Paulo, Caixa Postal 42494, 04218-970 São Paulo, SP, Brazil. manumfm@yahoo.com.br; ferdagosta@gmail.com

${ }^{2}$ Departamento de Biologia Animal e Vegetal, Universidade Estadual de Londrina, Caixa Postal 10011, 86057-970 Londrina, PR, Brazil. josebirindelli@yahoo.com
} 


\section{Material and Methods}

Counts and measurements follow Fink \& Weitzman (1974), with the addition of head depth, measured at vertical through the posteriormost tip of bony opercle. Horizontal scale rows below lateral line were counted to the pelvicfin insertion, not including the small scale at pelvic-fin insertion, which may be absent. Counts are followed by their absolute frequency of occurrence in parentheses; asterisks indicate the count of the holotype. Measurements are given as percents of standard length (SL), except subunits of the head, which are given as percents of head length. Supraneurals, branchiostegal, gill-rakers of first branchial arch, tooth cusps, unbranched anal-fin rays, procurrent caudal-fin ray counts and position of pterygiophores were taken from cleared and stained (c\&s) specimens, prepared according to Taylor \& Van Dyke (1985). Vertebrae of the Weberian apparatus were counted as four elements and the fused PU1+U1 of the caudal region as a single element. Color in life was based on Fig. 1a. Catalog numbers are followed by the number of specimens in alcohol and the SL range, and if any, the number of c\&s specimens and their SL range. Males and females or immature were sexed based on the elongation of the fins. The positive correlation between sex and fin elongation was confirmed on four specimens, with examination of the gonads under a stereomicroscope. Data from species of Hemigrammus, Hyphessobrycon, and Moenkhausia were taken directly from the specimens (see Comparative Material), or from original descriptions and redescriptions: Géry (1977) (for Hyphessobrycon scholzei), Zarske \& Géry (2004) (for Hyphessobrycon nigricinctus), García-Alzate et al. (2008) (for Hyphessobrycon paucilepis, $H$. sovichthys, and H. tuyensis), and Zarske (2011) (for Hemigrammus filamentosus). Museum abbreviations are: DZSJRP, Departamento de Zoologia e Botânica, Universidade Estadual Paulista “Júlio de Mesquita Filho”, Câmpus de São José do Rio Preto, São José do Rio Preto; INPA, Instituto Nacional de Pesquisas da Amazônia, Manaus; MCP, Museu de Ciências e Tecnologia, Pontifícia Universidade Católica do Rio Grande do Sul, Porto Alegre; MZUEL, Museu de Zoologia da Universidade Estadual de Londrina, Londrina; MZUSP, Museu de Zoologia da Universidade de São Paulo, São Paulo; SU (= CAS-SU), California Academy of Sciences specimens received from Stanford University, San Francisco; ZUEC, Museu de Zoologia da Universidade Estadual de Campinas "Adão José Cardoso", Campinas. Subdivisions of the rio Tocantins basin follow the definition of Ribeiro et al. (1995).

\section{Results}

\section{Hyphessobrycon ataktos, new species Figs. 1-2}

Moenkhausia sp. Menezes, Oyakawa \& Birindelli, 2013: 31, fig. 15 [same picture as Fig. 1a].

Holotype. MZUSP 113725, 37.7 mm SL, Brazil, Tocantins State, Natividade, córrego Cocal on road TO-280, rio Manoel Alves drainage, rio Tocantins basin, $11^{\circ} 42$ ' $50.2^{\prime \prime} \mathrm{S} 47^{\circ} 35^{\prime} 40.2^{\prime \prime} \mathrm{W}, 2 \mathrm{Dec}$ 2012, J. Birindelli, F. Dagosta, M. Loeb \& C. Santos.

Paratypes. All from Brazil, Tocantins State, rio Tocantins basin. DZSJRP 18431, 5, 26.2-29.5 mm SL; INPA 39537, 5, 25.3-28.3 mm SL; MCP 47869, 5, 23.3-33.1 mm SL; MZUEL 7019, 5, 23.628.5 mm SL; MZUSP 47846, 331, 9.1-36.8 mm SL, 11 c\&s, 20.3$32.6 \mathrm{~mm}$ SL, Natividade, Ribeirão da Sede, tributary of ribeirão Formiguinha at Fazenda São Judas, approximately $30 \mathrm{~km}$ north

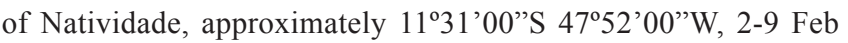
1994, F. C. T. Lima. MZUSP 43373, 5, 15.2-20.2 mm SL, Porto Nacional, left margin of rio Tocantins, 500 meters from bridge, $10^{\circ} 43^{\prime}$ S $48^{\circ} 25^{\prime}$ W, 9 Jun 1979, E. Bastos. MZUSP 43425, 4, 23.531.1 mm SL, Porto Nacional, Belém-Brasília road, 9 Jun 1979, E. Bastos. MZUSP 47864, 44, 13.2-35.2 mm SL, Natividade, Ribeirão da Represa, tributary of ribeirão Formiguinha at Fazenda São Judas, approximately $30 \mathrm{~km}$ North of Natividade, approximately

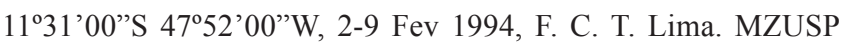
113722, 7, 17.6-34.4 mm SL, Almas, rio do Peixe at bridge on TO-280, 1140'0.7'S 47²6'19.9'W, 2 Dec 2012, J. Birindelli, F. Dagosta, M. Loeb \& C. Santos. MZUSP 113724, 18, 17.1-36.3 $\mathrm{mm}$ SL, same data as holotype. MZUSP 1131726, 2, 29.8-33.6 mm SL, Dianópolis, córrego Gameleira, 11³7’34.8”S 4656’25.4”W, 2 Dec 2012, J. Birindelli, F. Dagosta, M. Loeb \& C. Santos. MZUSP 113727, 1, 19.7 mm SL, Dianópolis, rio Mombó at road TO-280, 11²9'53.6”S 4650’32.3”W, 2 Dec 2012, J. Birindelli, F. Dagosta, M. Loeb \& C. Santos. MZUSP 113728, 1, 19.1 mm SL, Rio da Conceição, balneário at rio Manoel Alves, 11²4'12.9”S 46'51'30.3'W, 3 Dec 2012, J. Birindelli, F. Dagosta, M. Loeb \& C. Santos. ZUEC 6756, 4, 27.4-33.6 mm SL, Gurupi-Aliança do Norte road, Fazenda Suely, Jul 1981, J. Pombal-Jr.

Non-type material. CAS (SU) 56087, 4, 22.0-31.2 mm SL, Brazil, Goiás, “Laguinha II”, Santa Teresa Valley, 6 Jan 1924, C. Ternetz. CAS (SU) 56305, 1, 31.7 mm SL, Brazil, Goiás, "Jausinho brook into rio Tocantins" (not located), 22 Feb 1924, C. Ternetz.

Diagnosis. Hemigrammus ataktos can be distinguished from all congeners by its unique color pattern, consisting of a black midlateral stripe on body, extending from the posterior margin of the eye to the median caudal-fin rays (vs. dark stripe or thin line extending approximately from the humeral blotch or from 
the vertical through dorsal-fin origin to the caudal fin). The elongated anteriormost portions of the dorsal, pelvic, and anal fins in mature males also help to recognize the new species, feature only shared with $H$. filamentosus Zarske.

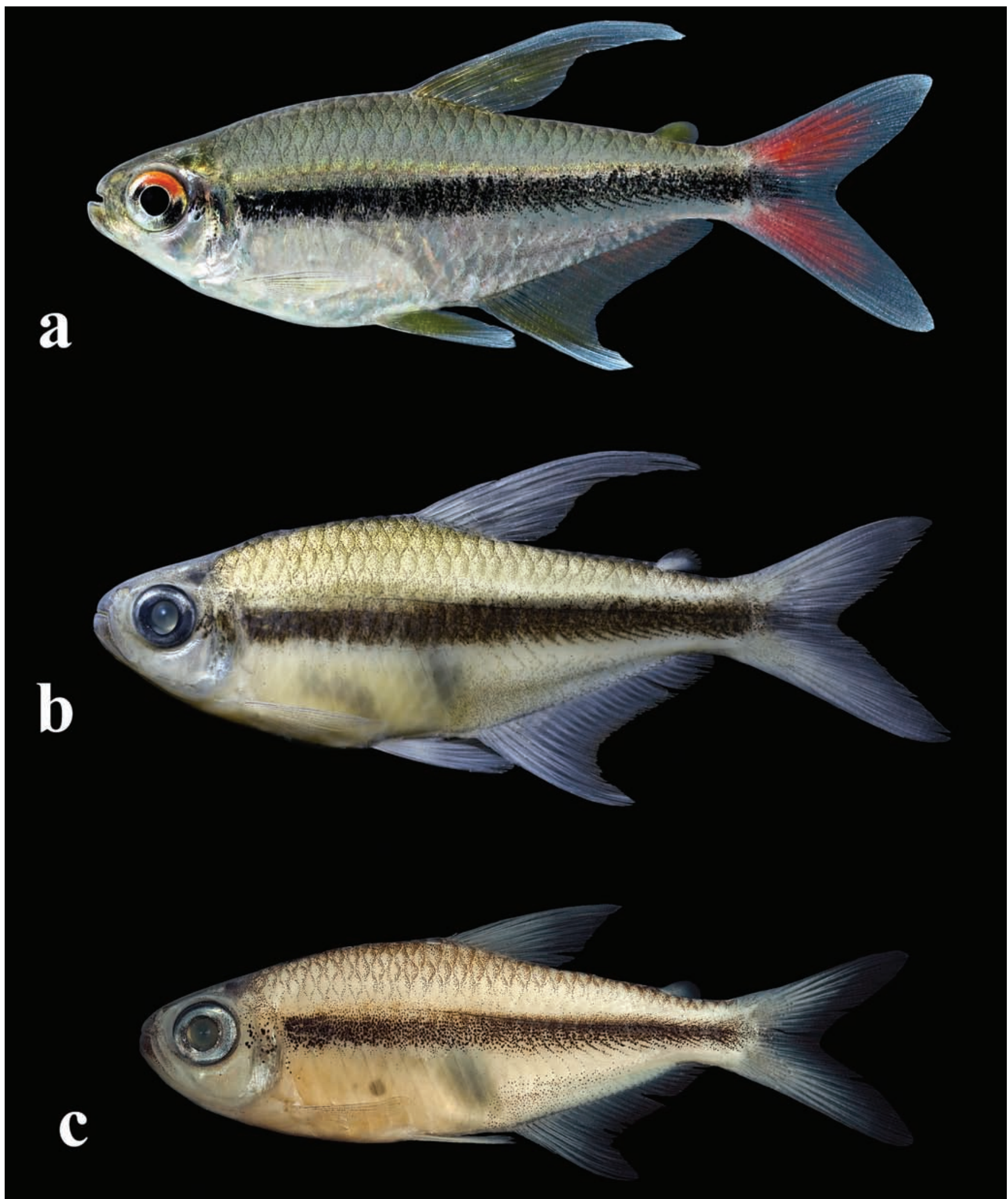

Fig. 1. Hemigrammus ataktos, holotype, MZUSP 113725, $37.7 \mathrm{~mm}$ SL, male (a) photographed alive, (b) after preservation; (c) MZUSP 113724, paratype, $33.0 \mathrm{~mm}$ SL, female, rio Manoel Alves drainage, rio Tocantins basin, Natividade, Tocantins State, Brazil. 
Description. Morphometric data presented in Table 1. Smallsized species, largest examined specimen $37.7 \mathrm{~mm} \mathrm{SL}$. Body compressed, moderately elongate. Greatest body depth slightly anterior to dorsal-fin origin. Dorsal profile of head convex from upper lip to vertical through anterior nostril; straight to slightly convex from that point to tip of supraoccipital spine. Dorsal profile of body slightly convex along predorsal region, straight and posteroventrally inclined along dorsal-fin base, straight to slightly convex from terminus of dorsal-fin base to adipose-fin origin, and concave along caudal peduncle. Ventral profile of head and body straight to slightly convex from tip of lower jaw to pectoral-fin origin, convex from that point to anal-fin origin, straight and posterodorsally inclined along anal-fin base, and concave along caudal peduncle.

Jaws equal, mouth terminal. Premaxillary teeth in two rows. Outer row with 2(3), 3(20), or $4 *(18)$ tricuspid, rarely pentacuspid teeth. Inner row with $5 *(40)$ tri- or pentacuspid teeth. Tip of maxilla approximately at vertical through middle of second infraorbital. Maxilla with 1(3), 2*(18), 3(17), 4(3), or $5(1)$ tri- to pentacuspid teeth. Dentary with $4 *(41)$ large pentacuspid, one smaller tetra- or tricuspid, and series of 6-13 diminute conical, rarely tricuspid, teeth. Central median cusp in all teeth longer than lateral cusps (Fig. 2). Branchiostegal rays 4(11). First gill arch with 1(2), 2(5), or 3(4) rakers on hypobranchial, $9(5)$ or 10(6) rakers on ceratobranchial, 1(11)

Table 1. Morphometrics of Hemigrammus ataktos, $\mathrm{n}=$ number of specimens, $\mathrm{SD}=$ Standard Deviation.

\begin{tabular}{|c|c|c|c|c|c|}
\hline & Holotyp & $\mathrm{n}$ & Paratypes & Mean & SD \\
\hline Standard Length $(\mathrm{mm})$ & 37.7 & 30 & $26.6-37.7$ & 33.2 & - \\
\hline \multicolumn{6}{|c|}{ Percentages of Standard Length } \\
\hline Depth at dorsal-fin origin & 34.9 & 30 & $28.6-36.6$ & 33.1 & 2.1 \\
\hline Snout to dorsal-fin origin & 49.3 & 30 & $38.4-54.3$ & 50.5 & 2.6 \\
\hline Snout to pectoral-fin origin & 25.9 & 30 & $25.1-28.5$ & 26.9 & 0.9 \\
\hline Snout to pelvic-fin origin & 45.8 & 30 & $44.1-49.0$ & 46.4 & 1.3 \\
\hline Snout to anal-fin origin & 59.7 & 30 & $58.6-63.7$ & 61.3 & 1.4 \\
\hline Caudal-peduncle depth & 11.0 & 30 & $9.4-11.6$ & 10.6 & 0.6 \\
\hline Caudal-peduncle length & 10.8 & 30 & $8.0-12.8$ & 10.9 & 1.1 \\
\hline Pectoral-fin length & 22.9 & 30 & $20.8-24.7$ & 22.2 & 1.1 \\
\hline \multicolumn{6}{|l|}{ Pelvic-fin length } \\
\hline Males & 22.5 & 11 & $18.8-23.8$ & 21.7 & 1.6 \\
\hline Females/immatures & - & 16 & 0.3 & 18.0 & 1.0 \\
\hline Pelvic-fin origin to anal-fin & 16.5 & 30 & $14.3-18.5$ & 16.3 & 1.0 \\
\hline \multicolumn{6}{|l|}{ Dorsal-fin length } \\
\hline Males & 44.9 & 11 & $31.6-44.9$ & 35.6 & 3.7 \\
\hline Females/immatures & - & 16 & $28.1-32.9$ & 30.3 & 1.2 \\
\hline Dorsal-fin base length & 14.7 & 30 & $12.5-16.1$ & 14.4 & 0.9 \\
\hline \multicolumn{6}{|l|}{ Anal-fin length } \\
\hline Males & 27.3 & 11 & $23.1-27.3$ & 25.3 & 1.9 \\
\hline Females/immatures & - & 16 & $19.5-24.4$ & 22.3 & 1.1 \\
\hline Anal-fin base length & 33.4 & 30 & $29.0-33.5$ & 31.3 & 1.4 \\
\hline Eye to dorsal-fin origin & 37.2 & 30 & $35.5-48.9$ & 37.7 & 2.4 \\
\hline Dorsal-fin origin to caudal-fin base & 52.8 & 30 & $48.3-54.5$ & 51.6 & 1.5 \\
\hline Head depth & 27.2 & 30 & $23.5-30.4$ & 26.5 & 1.4 \\
\hline Head length & 23.7 & 30 & $23.7-26.7$ & 25.0 & 0.8 \\
\hline \multicolumn{6}{|c|}{ Percentages of Head Length } \\
\hline Horizontal eye diameter & 42.8 & 30 & $23.0-$ & 44.1 & 5.7 \\
\hline Snout & 26.1 & 30 & $21.7-33.5$ & 25.5 & 2.0 \\
\hline Interorbital width & 35.3 & 30 & $31.4-36.8$ & 33.6 & 1.4 \\
\hline Upper jaw length & 44.6 & 30 & $43.1-50.1$ & 46.3 & 1.7 \\
\hline
\end{tabular}

raker on intermediate cartilage, and 5(2),6(8), or 7(1) rakers on epibranchial. Gill rakers with small spines along its length.

Scales cycloid, with four to seven radii on posterior border, and conspicuous circulii anteriorly. Lateral line straight to slightly curved ventrally, with total of 32(2), 33(31), 34(40), 35(24), or $36^{*}(4)$ scales. Scales on lateral line series variably perforated. Four specimens with 33(2), 34(1), and 35(1) completely pored lateral line; 65 specimens with 6(4), 8(5), 9(11), 10(9), 11(12), $12(8), 13(6), 14(6)$, or 15(4) pored scales followed by non-pored ones (incomplete lateral line), and 31 specimens with pored scales interspersed with non-pored ones (discontinuous lateral line) of variable pattern. Holotype with 19 pored +7 non-pored +2 pored +1 non-pored +6 pored lateral-line scales. Longitudinal scale rows between dorsal-fin origin and lateral line $5 *(29)$ or 6(1). Longitudinal scale rows between lateral line and pelvic-fin origin $3 *(22)$ or $4(8)$. Predorsal scales $10 *(21), 11(5)$, or 12(4), in one series. Single row of 4(2), 5(6), $6^{*}(11), 7(4)$, or 8(2) scales at base of anteriormost anal-fin rays. Circumpeduncular scale rows 14(30). Caudal fin with small scales along proximal one-fourth of upper lobe and proximal one-half of lower lobe. Supraneurals $4(7)$ or 5(3), with dorsal portion expanded.

Dorsal-fin rays ii(41), 9*(40) or 10(1). Proximal tip of dorsal-fin pterygiophore inserted posterior to neural spine of $9^{\text {th }}$ or $10^{\text {th }}$ vertebra. Base of last dorsal-fin ray at vertical through base of first or second branched anal-fin rays. Pectoral-fin rays i(30), 10(17), 11*(22), or 12(1). Pelvic-fin rays i(41), $7^{*}(41)$. Adipose-fin origin at vertical through base of $18^{\text {th }}$ or $19^{\text {th }}$ branched anal-fin rays. Anal fin falcate, with iv(1), v(9), vi(1), 20(2), 21(6), 22(14), 23*(15), or 24(4) rays. Proximal tip of first anal-fin pterygiophore inserted posterior to haemal spine of $15^{\text {th }}(2)$ or $16^{\text {th }}(4)$ vertebra. Caudal-fin with i(39), 9(39) rays on the upper and 8(39), i(39)* rays on the lower lobe. Caudal fin forked, with similar sized lobes. Dorsal procurrent caudalfin rays 10(2), 11(7), or 12(2); ventral procurrent caudal-fin rays $9(9)$ or 10(1). Total vertebrae 33(4) or 34(3): precaudal vertebrae 14(2) or 15(5) and caudal vertebrae 18(2) or 19(5).

Color in alcohol. Overall ground color light tan. Infraorbital, opercular and gular areas with guanine (Fig. 1b, c). Dorsal portion of head dark. Snout, maxilla, and lower jaw scattered with dark chromatophores. Dorsalmost three horizontal scale rows on body with slightly reticulated pattern, formed by dark pigment on middle portion of exposed area of scales. Deep black midlateral stripe on body, extending from posterior margin of eye to median caudal-fin rays. Stripe one-and-ahalf scales deep. Narrow longitudinal dark line at horizontal septum, formed by embedded dark chromatophores, extending approximately from vertical through dorsal-fin origin to end of caudal peduncle. Scattered dark chromatophores above anal-fin base. All fins with dark chromatophores along edge of lepidotrichia. Distal margin of third to fifth branched dorsal fin-rays and smallest branched anal-fin rays dark. 


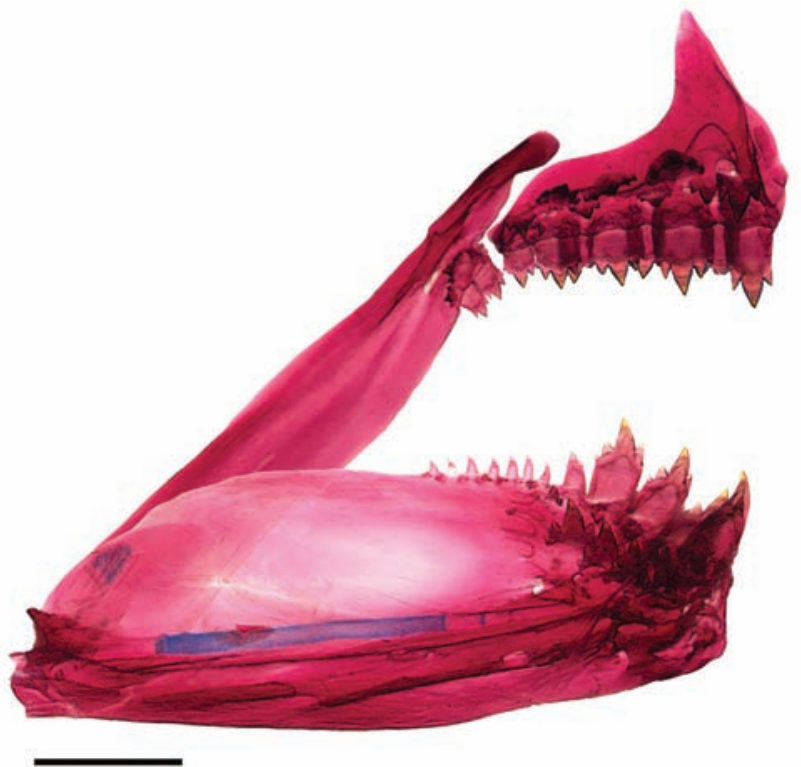

Fig. 2. Medial view of left side, upper and lower jaws of Hemigrammus ataktos, MZUSP 47846, paratype, $33.7 \mathrm{~mm}$ SL. Scale bar $=1 \mathrm{~mm}$.

Color in life. Dorsal portion of body yellowish tan above black midlateral stripe (Fig. 1a). Opercular area and ventral portion of body below black midlateral stripe with guanine. Narrow bright yellow line above black midlateral stripe. Black midlateral stripe over middle portion of eye. Dorsal portion of eye red, ventral portion silver. Tip of dorsal, pelvic, and anal fins creamy white. Adipose fin, most of dorsal and pelvic fins, and proximal portion of anteriormost rays of anal fin yellow. Proximal two-thirds of caudal-fin lobes red on mature males (no information available for females and juveniles).

Sexual dimorphism. Mature males with dorsal (31.6-44.9\% of SL), pelvic (18.8-23.8\% of SL) and anal fin (23.1-27.3\% of SL) longer than females or immatures (28.1-32.9\%; 15.8$20.3 \%$; $19.5-24.4 \%$, respectively) (Table 1, Fig. 3). Tip of pelvic fin extending from base of first to fifth branched analfin ray in mature males and not reaching anal fin or extending to base of first branched anal-fin ray in females. Bony hooks were not observed on fins of any analyzed specimen.

Geographic distribution. Hemigrammus ataktos is known from middle rio Tocantins basin, from rio Santa Tereza, Goiás State, from the rio Manoel Alves basin, and from smaller tributaries of the rio Tocantins immediately downstream of the mouth of rio Manoel Alves, Tocantins State, Brazil (Fig. 4).

Etymology. From the Greek ataktos, meaning disordered or irregular, in allusion to the variation in the perforation of lateral-line scales present in the new species. An adjective.
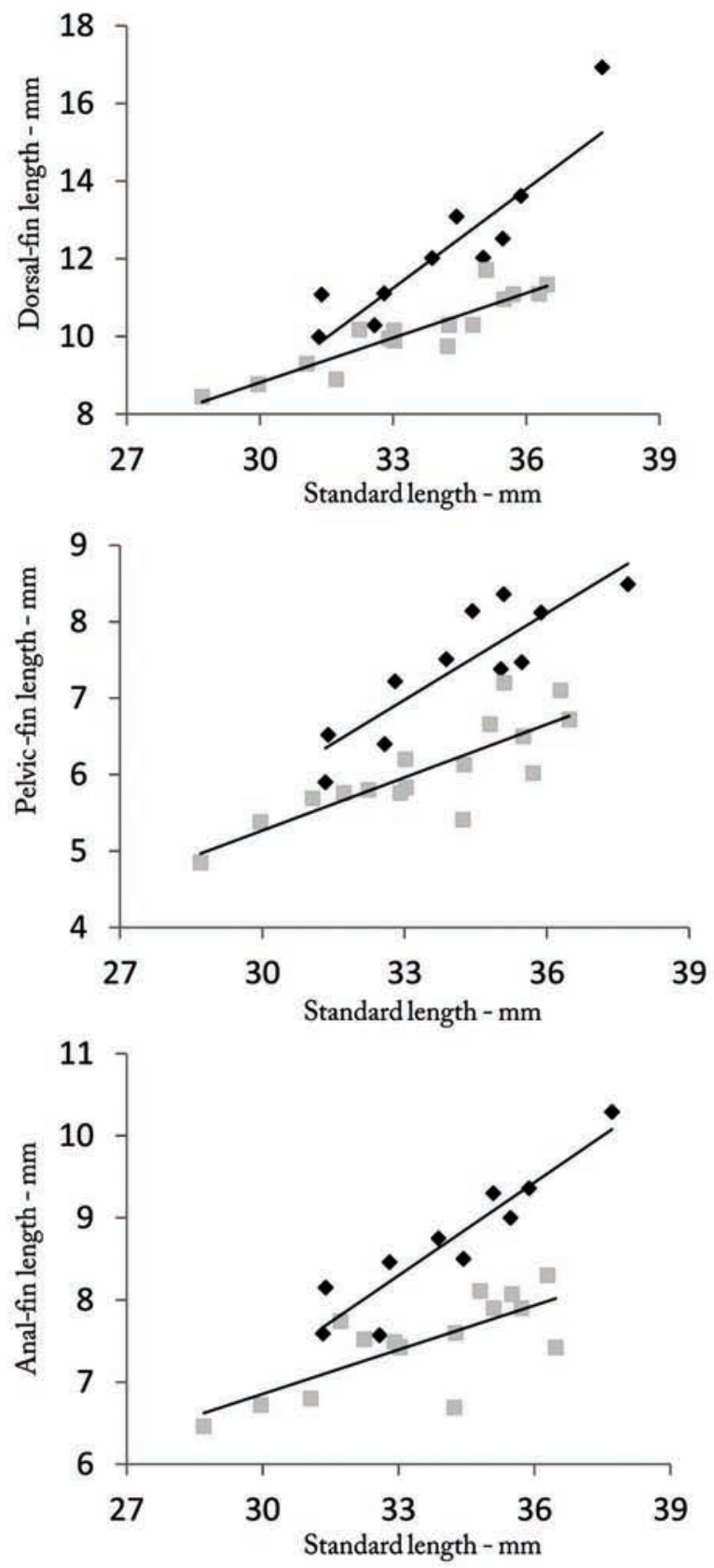

Fig. 3. Fin lengths as function of standard length in males (dark diamonds) and females (light squares) of Hemigrammus ataktos: (a) dorsal fin, (b) pelvic fin, and (c) anal fin.

Remarks. Specimens from CAS collection were designated as non-type material due to their poor condition.

\section{Discussion}

The traditional classification of the Characidae, established by Eigenmann (1917) and later followed by Géry (1977), greatly influenced the current classification of both subfamilial and generic levels. Several genera of the Characidae were proposed based on combination of morphological characters, 
including characteristics now known to have independently evolved within different lineages of the family (e.g., length of poring on lateral line, tooth-cusp morphology, caudal-fin squamation). Although this procedure was in general effective for alpha taxonomy, it resulted in an artificial delimitation of many non-monophyletic groups of species. This is the case for the most diverse characid genera, such as Hemigrammus (54 species), Hyphessobrycon (130 species) and Moenkhausia (76 species) (Weitzman \& Fink, 1983; Lima et al., 2003; Eschmeyer, 2013). According to this classification, which is still being used to classify species (e.g., Carvalho et al., 2010; Marinho, 2010; Sousa et al., 2010; Bertaco et al., 2011a, 2011b; Ingenito et al., 2013), the genus Hemigrammus is diagnosed from Hyphessobrycon uniquely by the presence of small scales covering the proximal portion of the caudal-fin lobes (vs. absence), and from Moenkhausia by having an incompletely pored lateral line (vs. completely pored lateral line). Based on this system, part of the specimens of the new species would fit into Hemigrammus, whereas part would be best identified as Moenkhausia. Of a hundred examined specimens, 65 have incomplete, 31 have discontinuous, and 4 have complete lateral line (see Description). Variation of lateral line perforation within a species was also described for other small characids, including Hemigrammus barrigonae Eigenmann \& Henn, 1914, Moenkhausia celibela Marinho \& Langeani, 2010, Moenkhausia cotinho Eigenmann, 1908 [see also Eigenmann (1918) for more information on lateral line scale counts for M. cotinho], M. sanctaefilomenae (Steindachner, 1907) [lateral line scale counts of M. sanctaefilomenae

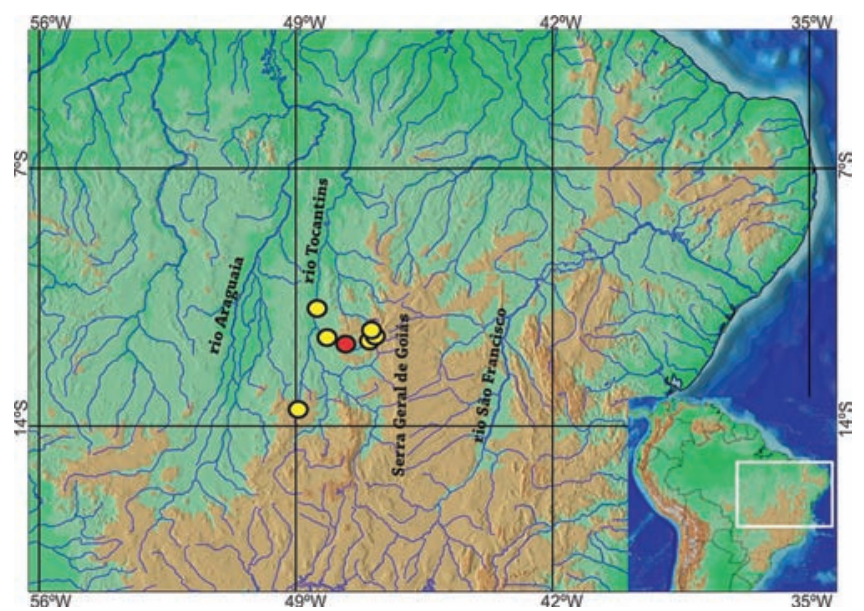

Fig. 4. Distribution of Hemigrammus ataktos in the middle rio Tocantins basin, central Brazil. Type locality represented by red circle.

discussed in Eigenmann (1917)] and Odontostilbe dialeptura Fink \& Weitzman, 1974. Lateral line reduction is hypothesized to have been independently acquired within several lineages in Characidae (Mirande, 2010), probably as a result of independent events of miniaturization, which may advance the presence of paedomorphic characters (Buckup 1998; Weitzman \& Fink, 1983; Weitzman \& Vari, 1988). Variation of lateral line perforation within a species may represent a key to understand mechanisms of truncation of the laterosensory canal system on body.

According to Mirande (2010), Hemigrammus, Hyphessobrycon, and Moenkhausia are non-monophyletic

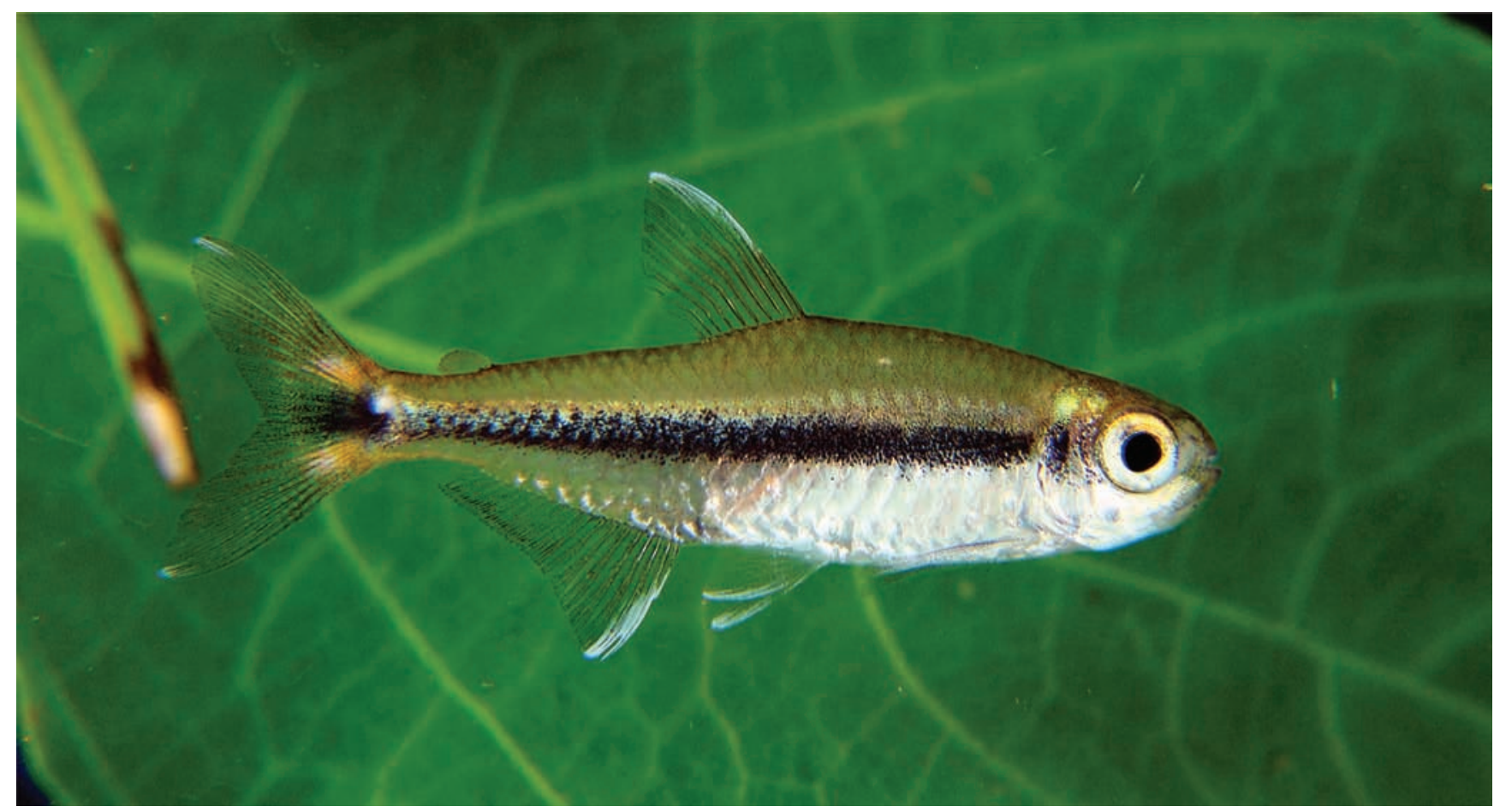

Fig. 5. Hyphessobrycon stegemanni, rio Tocantins basin, near Imperatriz, Maranhão, Brazil. Not preserved. Photo by D. Nielsen. 
groups, related to species of Bario Myers, 1940, Hasemania Ellis, 1911, Paracheirodon Géry, 1960, Pristella Eigenmann, 1908, and Thayeria Eigenmann, 1908. These genera are nested into a large clade named Tetragonopterinae (except for Hyphessobrycon anisitsi, $H$. bifasciatus, and $H$. luetkenii which were hypothesized to be more closely related to species of Astyanax). The unique synapomorphy proposed by Mirande (2010) for Tetragonopterinae, the presence of two pairs of uroneurals (character 306), is not shared by the new species, which has only one pair. However, several other species nested in Tetragonopterinae also has only one pair (e.g., clade 288 of Mirande, 2010). Although Hemigrammus ataktos probably belongs to this subfamily, a phylogenetic analysis is necessary to confirm this hypothesis.

A cladistic-based classification of Hemigrammus, Hyphessobrycon (Weitzman \& Palmer, 1997; Weitzman \& Malabarba, 1998), and Moenkhausia (Mirande, 2010) will probably result in generic reallocation of many species currently assigned to these genera. Pending further studies on the relationships of these genera, we tentatively assign the new species to Hemigrammus rather than Moenkhausia, because most of the examined specimens fit the traditional definition of the former genus. The new species can be distinguished from all species of Moenkhausia, except M. eurystaenia Marinho, 2010, M. heikoi Géry \& Zarske, 2004, and M. phaeonota Fink, 1979, by having a dark midlateral stripe from opercle to caudal peduncle (vs. stripe, when present, originating approximately at vertical through dorsal-fin origin). It is distinguished from Moenkhausia eurystaenia, M. heikoi and M. phaeonota by having elongate anteriormost dorsal and anal-fin rays on mature males (vs. not elongate). The new species is further distinguished from M. heikoi and M. phaeonota by the absence of humeral blotch (vs. present) and from M. eurystaenia by having a conspicuous black relatively narrow midlateral stripe on body (vs. midlateral stripe broader and not conspicuous).

Although Hemigrammus ataktos has a unique color pattern among its congeners, its color pattern is similar to some species of Hyphessobrycon referred by Géry (1977) as the Hyphessobrycon heterorhabdus-group, including $H$. cachimbensis Travassos, 1964, H. coelestinus Myers, 1929, H. heterorhabdus Ulrey, 1894, H. scholzei Ahl, 1937, H. sovichthys Schulz, 1944, H. stegemanni Géry, 1961, and H. vilmae Géry, 1966. Other Hyphessobrycon species subsequently described, or not cited by Géry (1977) with similar color pattern are: H. amapaensis Zarske \& Géry, 1998, H. cyanotaenia Zarske and Géry, 2006, H. fernandezi FernándezYépez, 1972, H. melanostichos Carvalho and Bertaco, 2006, H. nigricinctus Zarske and Géry, 2004, H. paucilepis GarcíaAlzate et al., 2008, and H. tuyensis García-Alzate et al., 2008. In addition to the presence of scales partially covering the caudal-fin lobes, Hemigrammus ataktos can be distinguished from all the aforementioned species by having the dorsal, pelvic and anal fins elongate in mature males (vs. not elongate or only anal-fin slightly elongate in $H$. nigricinctus). It can be further distinguished from all the above-mentioned species, except $H$. fernandezi, $H$. paucilepis, $H$. sovichthys, $H$. stegemanni, $H$. tuyensis, and $H$. vilmae by the absence of humeral blotch (vs. presence). It is distinguished from $H$. fernandezi and $H$. scholzei by the absence of caudal-fin spot, from $H$. paucilepis by the presence of 32-36 scales on the lateral series (vs. 28-29), from $H$. sovichthys by having 3-4 horizontal scale rows below lateral line series (vs. 5), from $H$. stegemanni by the presence of 20-24 branched anal-fin rays (vs. 16-18), and from $H$. vilmae by having an anal-fin profile furcated on males (vs. straight). It is further distinguished from $H$. amapaensis and $H$. heterorhabdus by the dark midlateral stripe extending from posterior portion of the orbit (vs. extending from opercle) and by the absence of a red longitudinal line on body when alive (vs. longitudinal red line present).

Hemigrammus ataktos has commonly been identified as Hyphessobrycon stegemanni in the aquarium trade. In fact, they are similar species in external morphology and are collected sympatrically in the rio Tocantins drainage (Fig. 5). Hemigrammus ataktos, however, can be easily distinguished from Hyphessobrycon stegemanni by the dorsal and anal fins elongate in mature males (vs. not elongate), inner premaxillary teeth with 3-5 cusps (vs. 7-9), larger dentary teeth with 5 cusps (vs. 7-9) caudal-fin lobes covered largely by scales (vs. scales restricted to caudal-fin base), and 20-24 branched anal-fin rays (vs. 16-18).

Comparative material. Brazil. Distrito Federal: Hyphessobrycon coelestinus: MZUSP 93128, 49, 14.7-26.5 mm SL, rio Paranaíba basin. Mato Grosso State: Hyphessobrycon melanostichos: MZUSP 89646, 25, 18.6-34.4 mm SL, rio Tapajós basin. Hyphessobrycon vilmae: MZUSP 61128, 87, 14.2-25.7 mm SL, rio Tapajós basin. Moenkhausia eurystaenia: MZUSP 106058, holotype, $36.8 \mathrm{~mm}$ SL, rio Xingu basin. Moenkhausia phaeonota: MZUSP 13793, holotype, $32.3 \mathrm{~mm}$ SL, rio Tapajós basin. MZUSP 13794, paratype, 1, 19.3 mm SL, rio Tapajós basin. MZUSP 13795 , paratype, $20.7 \mathrm{~mm}$ SL, rio Tapajós basin. Pará State: Astyanax dnophos: MZUSP 82460, paratypes, 3, 29.5-33.2 mm SL, rio Xingu basin; Hyphessobrycon cachimbensis: MZUSP 96823, 500, 23.3$49.1 \mathrm{~mm}$ SL, rio Tapajós basin; Hyphessobrycon heterorhabdus: MZUSP 105757, 17, 21.7-26.3 mm SL, coastal drainage of Pará State; Tocantins: Hyphessobrycon stegemanni: MZUSP 83989, 16, 17.6-23.2 mm SL, rio Tocantins basin. Tocantins. MZUSP 113723 , 21, 19.4-28.4 mm SL, rio Tocantins basin, MZUSP 113729, 15, 23.7-26.7 mm SL, rio Tocantins basin. MZUSP 113731, 2, 22.6-24.5 $\mathrm{mm}$ SL, rio Tocantins basin. Venezuela. Tucacas. Hyphessobrycon fernandezi: MZUSP 105445, 28, 8.6-22.3 mm SL, Tucacas.

\section{Acknowledgments}

We thank Fernando Carvalho (DZSJRP) and Flávio Lima (ZUEC) for the valuable suggestions on the manuscript, Flávio 
Lima (ZUEC) for collecting part of the paratypes, Tulio Teixeira (MZUSP) for helping with the sexual dimorphism section, Eduardo Baena (MZUSP) for preparing Fig. 1b, Dalton Nielsen (Unitau) for providing Fig. 5, Flávio Lima and Karina Elisiário (ZUEC) for the loan of specimens. Part of the type series was collected during an expedition funded by the South American Characiformes Inventory (FAPESP 2011/50282-7, http://www.projeto-saci.com). Two of the authors were funded by FAPESP (2009/15075-0, MMFM, and 2011/23419-1, FCPD).

\section{Literature Cited}

Bertaco, V. A., F. C. Jerep \& F. R. Carvalho. 2011a. A new characid fish, Moenkhausia aurantia (Ostariophysi: Characiformes: Characidae), from the upper rio Tocantins basin in central Brazil. Zootaxa, 2934: 29-38.

Bertaco, V. A., F. C. Jerep \& F. R. Carvalho. 2011b. New species of Moenkhausia Eigenmann (Ostariophysi: Characidae) from the upper rio Tocantins basin in central Brazil. Neotropical Ichthyology, 9: 57-63.

Buckup, P. A. 1998. Relationships of the Characidiinae and phylogeny of Characiform Fishes (Teleostei: Ostariophysi). Pp. 123-144. In: Malabarba, L. R., R. E. Reis, R. P. Vari, Z. M. Lucena \& C. A. S. Lucena. (Eds.). Phylogeny and Classification of Neotropical Fishes. Edipucrs, Porto Alegre.

Carvalho, F. R., V. A. Bertaco \& F. C. Jerep. 2010. Hemigrammus tocantinsi: a new species from the upper rio Tocantins basin, central Brazil (Characiformes: Characidae). Neotropical Ichthyology, 8: 247-254.

Eigenmann, C. H. 1917. The American Characidae. Part 1. Memoirs of the Museum of Comparative Zoology, 43: 1-102.

Eigenmann, C. H. 1918. The American Characidae. Part 2. Memoirs of the Museum of Comparative Zoology, 43: 103-208.

Eschmeyer, W. N. 2013. Catalog of Fishes, California Academy of Sciences. Available from: http://research.calacademy.org/ research/ichthyology/catalog/fishcatmain.asp/ (21 May 2013).

Fink, W. L. \& S. H. Weitzman. 1974. The so-called Cheirodontin fishes of Central America with description of two new species (Pisces, Characidae). Smithsonian Contributions to Zoology, 172: 1-46.

Fisch-Muller, S., A. R. Cardoso, J. F. Pezzi da Silva \& V. A. Bertaco. 2005. Three new species of Ancistrus Kner (Teleostei: Siluriformes: Loricariidae) from the upper Tapajós and Tocantins rivers. Revue suisse de Zoologie, 112: 559-572.

Fisch-Muller, S., R. Mazzoni \& C. Weber. 2001. Genetic and morphological evidences for two new sibling species of Ancistrus (Siluriformes: Loricariidae) in upper rio Tocantins drainage, Brazil. Ichthyological Exploration of Freshwaters, 12: 289-304.

García-Alzate, C. A., C. Román-Valencia \& D. C. Taphorn. 2008. Revision of the Hyphessobrycon heterorhabdus-group (Teleostei: Characiformes: Characidae), with description of two new species from Venezuela. Vertebrate Zoology, 58: 139-157.

Géry, J. 1977. Characoids of the World. Neptune City, New Jersey, T. F. H. Publications.

Ingenito, L. F. S., F. C. T. Lima \& P. A. Buckup. 2013. Hyphessobrycon Durbin (Characiformes: Characidae) form the rio Juruena basin, central Brazil, with notes on H. loweae Costa \& Géry. Neotropical Ichthyology, 11: 33-44.

Lima, F. C. T., L. R. Malabarba, P. A. Buckup, J. F. P. Silva, R. P. Vari, A. Harold, R. C. Benine, O. T. Oyakawa, C. S. Pavanelli,
N. A. Menezes, C. A. S. Lucena, M. C. S. L. Malabarba, Z. M. S. Lucena, R. E. Reis, F. Langeani, L. Casatti, V. A. Bertaco, C. R. Moreira \& P. H. F. Lucinda. 2003. Genera Incertae sedis in Characidae. Pp. 106-169. In: Reis, R. E., S. O. Kullander \& C. J. Ferraris Jr. (Eds.). Check List of the Freshwater Fishes of South and Central America. Edipucrs, Porto Alegre.

Marinho, M. M. F. 2010. A new species of Moenkhausia Eigenmann (Characiformes: Characidae) from the rio Xingu basin, Brazil. Neotropical Ichthyology, 8: 655-659.

Mattox, G. M. T., R. Britz, M. Toledo-Piza \& M. M. F. Marinho. 2013. Cyanogaster noctivaga, a remarkable new genus and species of miniature fish from the Rio Negro, Amazon basin (Ostariophysi: Characidae). Ichthyological Exploration of Freshwaters, 23: 297-318.

Menezes, N. A., O. T. Oyakawa \& J. L. O. Birindelli. 2013. Inventário dos Characiformes Sul-Americanos (SACI): um projeto temático. Boletim Sociedade Brasileira de Ictiologia, 105: 25-31.

Mirande, J. M. 2010. Phylogeny of the family Characidae (Teleostei: Characiformes) from characters to taxonomy. Neotropical Ichthyology, 8: 385-568.

Ribeiro, M. C. L. B., M. P. Junior \& A. A. Juras. 1995. Ecological integrity and fisheries ecology of the Araguaia-Tocantins river basin, Brazil. Regulated rivers: research \& management, 11: 325-350.

Sousa, L. M., A. L. Netto-Ferreira \& J. L. O. Birindelli. 2010. Two new species of Moenkhausia Eigenmann (Characiformes: Characidae) from Serra do Cachimbo, Pará, northern Brazil. Neotropical Ichthyology, 8: 255-264.

Taylor, W. R. \& G. C. Van Dyke.1985. Revised procedures for staining and clearing small fishes and other vertebrates for bone and cartilage. Cybium, 9: 107-119.

Weitzman, S. H. \& W. L. Fink. 1983. Relationships of the neon tetras, a group of South American freshwater fishes (Teleostei, Characidae), with comments on the phylogeny of New World Characiformes. Bulletin of the Museum of Comparative Zoology, 150: 339-395.

Weitzman, S. H. \& L. R. Malabarba. 1998. Perspectives about the phylogeny and classification of the Characidae. Pp. 161-170. In: Phylogeny and Classification of Neotropical fishes. Malabarba, L. R., R. E. Reis, R. P. Vari, Z. M. S. Lucena \& C. A. S. Lucena (Eds.). Edipucrs, Porto Alegre.

Weitzman, S. H. \& L. Palmer. 1997. A new species of Hyphessobrycon (Teleostei: Characidae) from the Neblina region of Venezuela and Brazil, with comments on the putative 'rosy tetra clade'. Ichthyological Exploration of Freshwaters, 7: 209-242.

Weitzman, S. H. \& R. P. Vari. 1988. Miniaturization in South American freshwater fishes; an overview and discussion. Proceedings of the Biological Society of Washington, 101: 444-465.

Zarske, A. 2011. Hemigrammus filamentosus spec. nov. - der Südamerikanische Fadensalmler, ein neuer Salmler (Teleostei: Characiformes: Characidae) aus dem Araguaya-Becken in Brasilien. Vertebrate Zoology, 61: 3-12.

Zarske, A. \& J. Géry. 2004. Hyphessobrycon nigricinctus sp. n. ein neuer Salmler (Teleostei: Characiformes: Characidae) aus dem Stromgebiet des río Madre de Dios in Peru. Zoologische Abhandlungen; Staatliches Museum für Tierkunde in Dresden, 54: 31-38.

Submitted June 3, 2013 Accepted December 17, 2013 by George Mattox Published June 30, 2014 